ENERGETICS. HEAT ENGINEERING.

ELECTRICAL ENGINEERING

ЕНЕРГЕТИКА. ТЕПЛОТЕХНІКА.

ЕЛЕКТРОТЕХНІКА

UDC [621.65:534.122]:62-752

O.V. Korolyov, DSc, Prof.,

Zhou Huiyu

Odessa National Polytechnic University, 1 Shevchenko Ave., 65044 Odessa, Ukraine; e-mail: korolyov118@gmail.com

\title{
THE STUDY OF PRESSURE FLUCTUATIONS IN THE PRESSURE LINE OF THE PUMP AND OF THE EFFICIENCY OF THE VIBRATION ABSORBERS
}

\begin{abstract}
O.В. Корольов, Чжоу Хуіюй. Дослідження коливань тиску в напірній магістралі насосу і ефективності роботи гасителів коливань. У статті наведено результати експериментальних досліджень коливань тиску в трубопроводах поршневих насосів. Актуальність досліджень обумовлена необхідністю зниження коливань тиску, які утворюються об'ємними насосами, зважаючи на їх негативний вплив не тільки на надійність роботи насосів, але і на точність вимірювання витрати і тиску середовища, що подається такими насосами. Мета: Метою цього дослідження було вивчення гідравлічних характеристик пульсуючих потоків в напірних магістралях поршневих насосів скрапленого газу, а також дослідження ефективності роботи гасителів пульсацій тиску і відповідності їх параметрів розрахунковим. Матеріали і методи: Приводами використовувалися поршневі насоси - однолінійний і трилінійний. В ході випробувань фіксувалися коливання тиску в напірній магістралі. Для цього використовувалися малоінерційні датчики тиску на 15,0 МПа, що працюють в комплекті з тензостанцією, яка дозволяє реєструвати коливання тиску на частотах до 10 кГц. Вихідний сигнал тензостанціі подавався на вхід осцилографа, працюючого в режимі запам'ятовування. При всіх випробуваннях датчики тиску встановлювалися в трьох точках - після поршневої групи, на напірній магістралі перед демпфуючим пристроєм і за ним. В експерименті було використано три різні демпфери - два нові, розраховані за авторською методикою, і один штатний, яким укомплектовані серійні поршневі насоси. Демпфери встановлювалися вертикально, введення потоку здійснювалося в нижню кришку, а виведення - через бічну поверхню. Результати: Проведені експериментальні дослідження підтвердили загальне положення щодо більшої ефективності складних складених фільтрів і щодо правильності обраної методики їх розрахунку, запропонованої авторами раніше; зокрема, фактичний рівень послаблення коливань тиску на розробленому демпфері надзвичайно точно збігся з розрахунковими результатами.

Ключові слова: поршневий насос, демпфер, тиск, коливання.

O.V. Korolyov, Zhou Hиiуu. The study of pressure fluctuations in the pressure line of the pump and of the efficiency of the vibration absorbers. The article presents the results of experimental studies of pressure fluctuations in the pipes of piston pumps. The relevance of these studies is due to the need to reduce the pressure fluctuations that create a positive displacement pumps, due to their negative impact not only on the reliability of the pump, but the accuracy of flow measurement and pressure of the medium supplied to such pumps. Aim: The aim of this study was to investigate the hydraulic characteristics of pulsating flows in pressure lines piston pumps of liquefied gas, as well as the study of the effectiveness of the dampers of pressure pulsations and conformity of their parameters to the calculation. Materials and Methods: As a drive used the piston pumps - single-line and trilinear. In the tests recorded pressure fluctuations in the pressure line. For this purpose the low-inertia pressure sensors $15.0 \mathrm{MPa}$ working complete with strain test station, which allows registering the pressure fluctuations at frequencies up to $10 \mathrm{kHz}$. Strain test station output signal fed to the input of the oscilloscope operating in memory mode. In all tests the pressure sensor is mounted at three points - after the piston group on the pressure line before the damping device and after it. In the experiment, three different damper was used - two new, designed by the author's method and one regular damper, which are equipped with serial piston pumps. Dampers installed vertically, the flow entering to the lower cap, and an output through the side surface. Results: The experimental results confirmed the general position of the greater efficiency of complex composite filters and the correctness of chosen method of their calculation, proposed earlier by the authors. In particular, the actual level of weakening of pressure fluctuations on developed damper with a high degree coincided with the calculated results.
\end{abstract}

Keywords: piston pump, damper, pressure fluctuations.

Introduction. The relevance of this study is due to the need to reduce pressure fluctuations that displacement pumps create. These fluctuations have negative impact not only on reliability of pumps, but also reduce the accuracy of flow measurement and pressure of the medium supplied by such pumps.

DOI 10.15276/opu.3.50.2016.08

(C) 2016 The Authors. This is an open access article under the CC BY license (http://creativecommons.org/licenses/by/4.0/). 
As an example, it may be noted several cases of destruction of the tanker of liquid nitrogen during their filling out with piston pumps, which occurred in 1986 at the localization of the Chernobyl accident.

The tasks of the study were to obtain information on the pressure fluctuations during normal pump operation and with a feed failure mode at different points of the stand. At the stands the absorbers of pressure fluctuations developed earlier by the authors [1] were investigated, as well as regular devices reducing the flow pressure fluctuations, calculated according to standard procedures [2...4]. In addition, to identify the comparative characteristics of the work of damping devices was among the objectives of the study.

The aim of this study was to investigate the hydraulic characteristics of pulsating flows in pressure lines piston pumps of liquefied gas, as well as the study of the effectiveness of the dampers and pressure pulsations and conformity of their parameters to calculation.

\section{Materials and Methods.}

Methods of experimental research and technical support for the experiment. The tests were conducted at the stands of the Odessa National Polytechnic University in the engine room of the Department of Atomic Power Plants and LLC "Krioprom" (Odessa, Ukraine).

As a drive the piston pumps are used, commercially available from LLC "Kislorodmash" single-line pump model 2NSG-0.063/20 and the trilinear pump 2NSG-0.42/15.

During the tests we recorded pressure fluctuations in the pressure line. For this purpose were used low-inertia pressure sensors LKh-417 for $P_{\mathrm{cr}}=15.0 \mathrm{MPa}$ which work complete with strain test station L-7000, which allows recording pressure vibrations at frequencies up to $10 \mathrm{kHz}$.

Strain test station the output signal is input to S8-13 oscilloscope operating in the memory mode, which allows to fix on the film the low frequency signals (up to $0.5 \mathrm{~Hz}$ ) coming from the pressure sensors. Shooting waveforms made directly from the screen of the oscilloscope by the camera Canon 10D with lens "Jupiter-37A".

In all tests the pressure sensor is mounted at three points - after the piston group, on the pressure line before the damping device and after it. Sensor installation diagram is shown in Fig. 1.

The numbering of the sensor goes from the pump to the damper and saved so during the registration and observational results processing. Pressure pipe is made of steel pipe Du20 with a hermetic part in the form of bellows from steel 12Kh18N9T.

On the stand three different dampers were installed - two new, calculated by the method described in [1], and one regular, which were equipped with piston pumps manufactured by LLC "Kislorodmash". Constructed by calculation the dampers were muffled on both sides the pipe segments $\varnothing 70 \times 7$ and length of 0.5 and $1.0 \mathrm{~m}$.

Dampers are installed vertically, low input carried in the lower cap, and an output through the side surface at a distance of $100 \mathrm{~mm}$ from the bottom cover of the damper. The yield was carried out through the orifice plate with diameter 4.0 and $5.0 \mathrm{~mm}$, respectively. Fig. 2 is a sketch of the dampers. Weight dampers were of 11.5 and $6 \mathrm{~kg}$ respectively. Orifice plate is designed as a Venturi.

The regular damper was a pulsation one of purely reactive type, where the damping pressure fluctuations were carried out at a flow passing through the container of volume about 10 liters with supported steam volume in the upper part. Creation and maintaining of the steam volume was ensured by evaporator.

The evaporator is an aluminum casting, which are filled with a coil of steel $12 \mathrm{Kh} 18 \mathrm{NIOT}$ and electric heating elements. Protection of elements against overheating carried out by means of sensorrelay temperature TR-K. The damper has a case in the intertube space of which super the thin glass fiber for insulation is placed. Total damper weight is $70 \mathrm{~kg}$.

In the trilinear pump two different drive frequency mode - 1000 and $1500 \mathrm{rpm}$, respectively, as well as features of the pump operations in the normal and shear mode were investigated. To simulate a pump failure mode, the device that allows pressing of the valve seat directly on the running pump was used. 


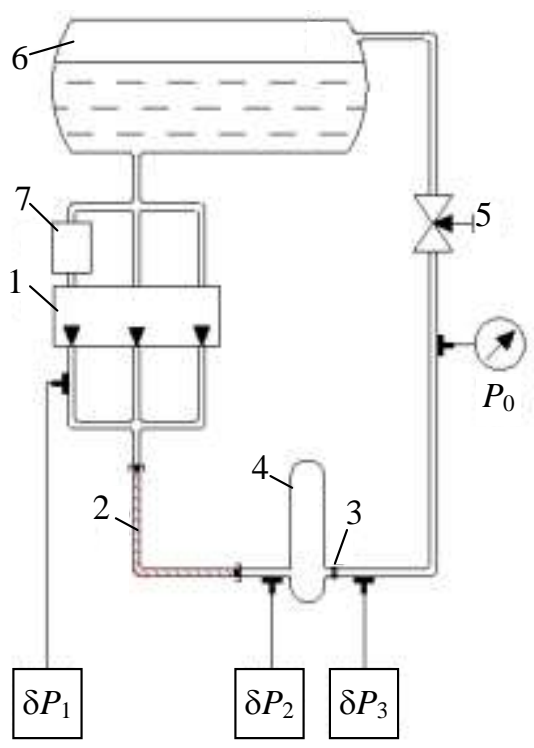

Fig. 1. Diagram of the experimental stand with indication of the pressure measuring points: 1 trilinear pump; 2 - pressure line hose; 3 - throttle orifice; 4 damper; 5 - a control valve; $6-$ thermally insulated container; 7 feeder of failure

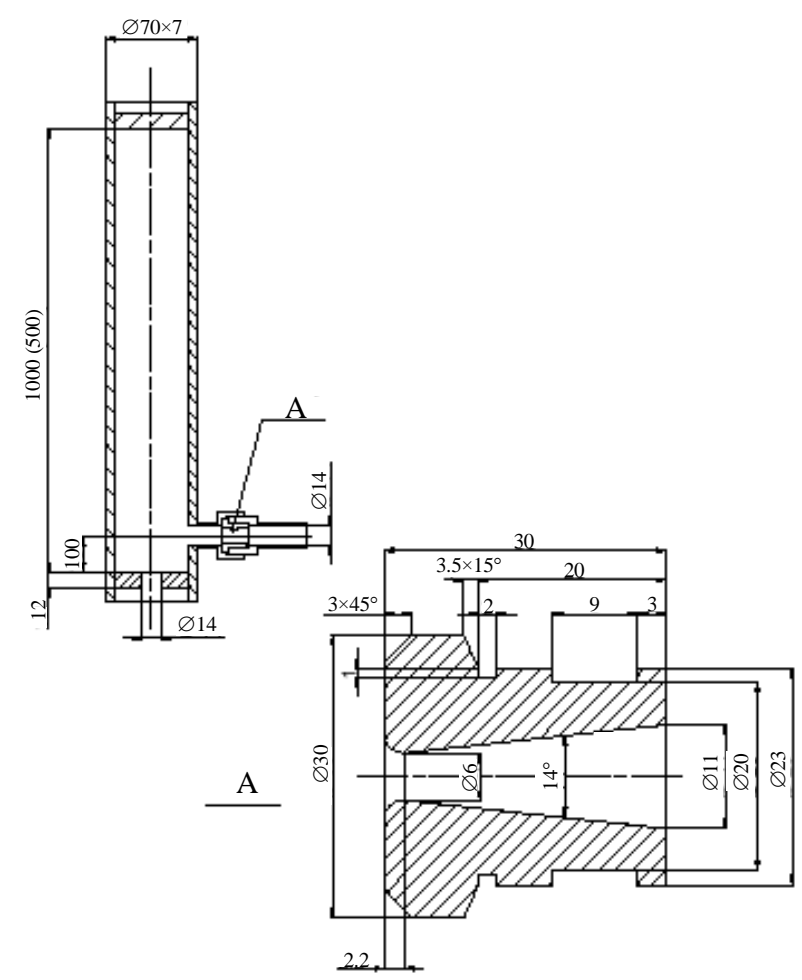

Fig. 2. Sketch of damper-absorber of pressure fluctuations and the throttle washer in the form of Venturi nozzle

Results and Discussion. Research conducted on the stands have shown, that during normal pump operation, as well at failure is not observed purely harmonic signal form, which indicates the presence of impact origin noise (Fig. 3 and 4).

When failure of one of the pump stages (in the three-way pump) pressure failure occurs in the phase of stripped stage. However, this failure does not reach the pressure values at suction and, depending upon the mode of operation of the pump, makes $300 \ldots 400 \%$ of the pressure pulsation in the normal mode (this is $20 \ldots 40 \%$ of the nominal discharge pressure). When you remove measuring point from the compressor the noise of impact character pressure is smoothed (weaken), clearly visible the fundamental harmonic on the frequency of piston stroke and pressure variations during the passage through the damper are attenuated. Fig. $6 \ldots 10$ shows the results of measurements of the average value of pressure pulsations $\delta P_{i}$ towards the discharge pressure $\delta P_{i}$ at three points of measurement along the length of the discharge pipe. The average value of the pressure pulsations determined as the average of the five maximum values of pressure fluctuations registered during the five seconds of the implementation of the process at the oscillogram.

The figures presented below shows that the dampers installed in pressure line have different effects on the pressure fluctuations along the pipeline. Thus the installation on the stand of the regular damper or damper $H=0.5 \mathrm{~m}$ leads to the increasing in pressure fluctuations before the damper (Fig. 5 and 6) in 1.5...2 times in comparison with the pressure fluctuation just after piston.

A feature of these dampers is that the relative pressure fluctuations in the supply failure mode for the drive pump frequency $n=1500 \mathrm{rpm}$ reaches its greatest value at a discharge pressure of $15.0 \mathrm{MPa}$, and at a frequency of $n=1000 \mathrm{rpm}$ with pressure of $100 \mathrm{MPa}$.

Research of a level of pressure fluctuations reducing in the normal pump operation mode has shown that the regular damper reduces the pressure pulsation to $1.3 \ldots 1.8 \%$ for pump drive frequency $n=1500 \mathrm{rpm}$ and up to $2 \ldots 2.5 \%$ for $n=1000 \mathrm{rpm}$. The damper $H=0.5 \mathrm{~m}$ smooths out the pressure pulsations up to $0.9 \ldots 1.4$ and $0.6 \ldots 1.0 \%$ for the respective pump drive frequencies. However, in mode of failure to supply the smoothed pressure fluctuation for the regular damper reach the values of 
$6 \ldots 10 \%$ and $4 . .5 .5 \%$ from the initial pressure for damper $H=0.5 \mathrm{~m}$. Obviously, these dampers do not satisfy the operating conditions of piston pumps.

The best indicators in the tests had a damper $H=1.0 \mathrm{~m}$, specially designed for working on carbon dioxide (Fig. 7 and 8).

First, the installation of the damper to the stand does not increase the pressure upstream of the damper, as it was in first two cases. Second, the value of the smoothed pressure pulsations reached the calculated values of $0.5 \ldots 1.0 \%$ of the initial pressure (the pressure at the outlet of the pump) and did not change when you change the frequency of the pump. And the third, smooth the pressure pulsations in the pump failure does not exceed 2.0...2.5\% of the initial pressure, which is in 2...4 times lower than the values given in this case by other dampers.

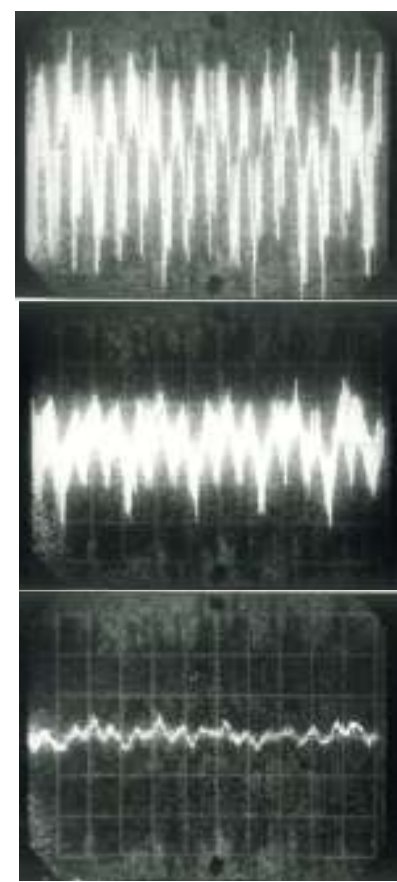

$a$

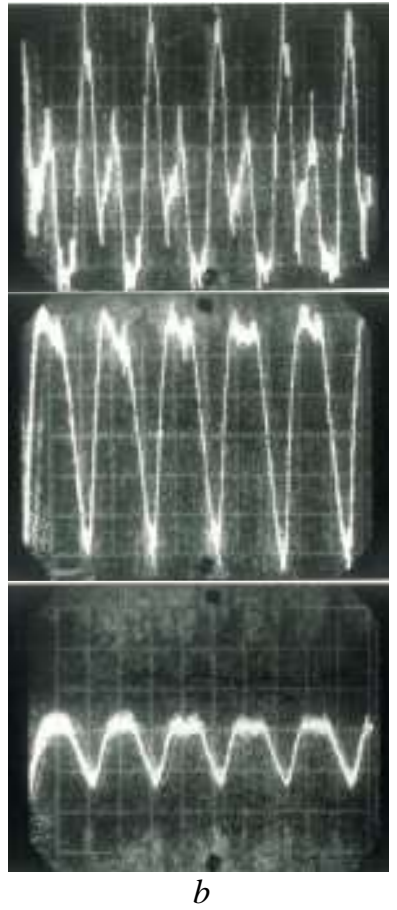

Fig. 3. Oscillograms of pressure fluctuation (damper

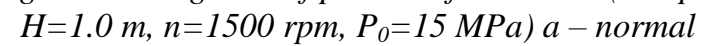
operation mode; $b$ - mode of supply failure

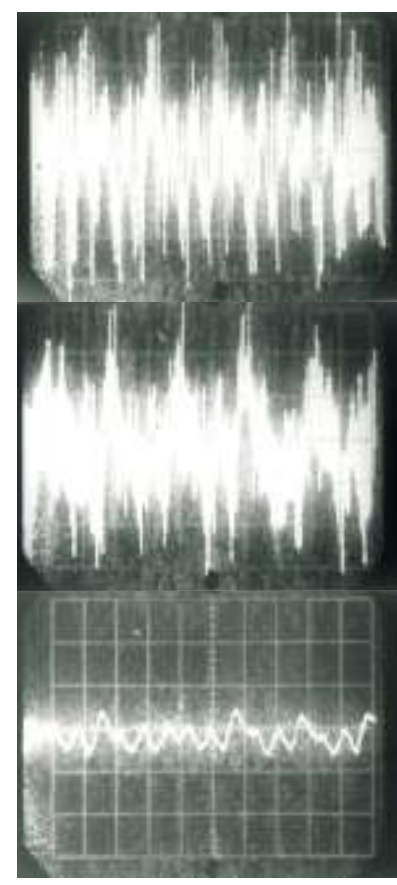

$a$

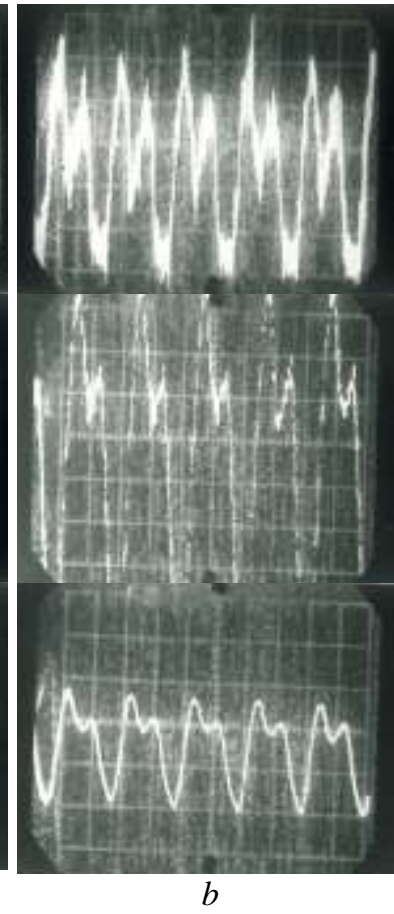

Fig. 4. Oscillograms of pressure fluctuation (regular damper, $n=1500 \mathrm{rpm}, P_{0}=15 \mathrm{MPa}$ ) $a$-normal operation mode; $b$-mode of supply failure

The damper $H=1.0 \mathrm{~m}$ also was tested in teamwork with single piston pump. The results of analysis of experimental data is presented in fig. 10, which shows that the smoothed pressure pulsation does not exceed $1 \%$ in the pressure range of $10 \ldots 20 \mathrm{MPa}$ from the initial pressure, and the pressure pulsations on damper decreased in 13.6 times in average.

As in the case of trilinear pump, the pressure fluctuation along the pressure line is reduced.

Thus, the test of the damper $H=1.0 \mathrm{~m}$ showed good correlation of calculated characteristics with characteristics identified from the experiment, and confirmed its high efficiency in order to reduce the pressure fluctuations both the single-line and in the three-way pump.

Comparing weight and size characteristics of the regular damper and damper $H=1.0 \mathrm{~m}$, also goes in favor of the latter: the damper mass is reduced by almost 7 times. The process of damper manufacturing simplified greatly.

The experiment confirmed the general position of the greater efficiency of complex composite filters, and the correctness of the chosen method of their calculation.

Below are the pressure fluctuations waveforms after the piston pump (at point 1 in Fig. 1), the pressure fluctuation before and after damper (at point 2 and 3, respectively). At all oscillograms, the 
time scale is 0.05 seconds per graduation mark. The scale of the pressure in the presented oscillograms is $0.28 \mathrm{MPa}$ per graduation mark.

Here, Fig. 5...9 shows the pressure fluctuations change along the length of line in a graphical form, which also visually confirm earlier conclusions.

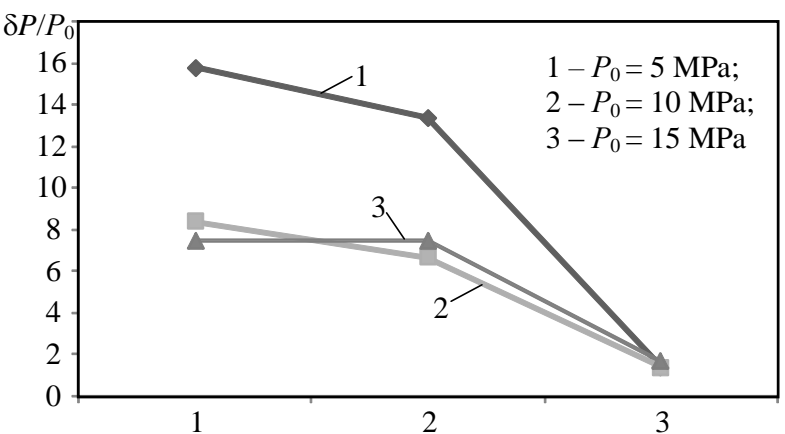

Fig. 5. The relative magnitude of pressure fluctuations along the length of line: regular damper, $n=1500 \mathrm{rpm}$, the normal operating mode

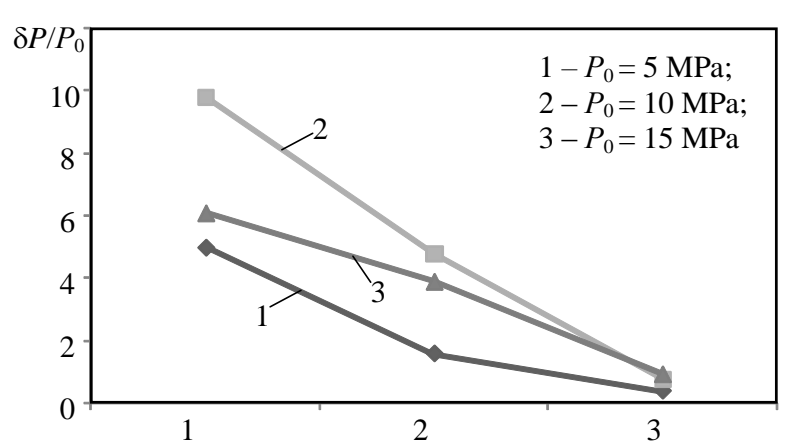

Fig. 7. The relative magnitude of pressure fluctuations along the length of line: damper $H=1.0 \mathrm{~m}, n=1500 \mathrm{rpm}$, normal operating mode

Conclusions. Comparison of weight and size characteristics of the regular damper and damper with $\mathrm{H}=1.0 \mathrm{~m}$ showed the effectiveness of the latter: damper mass is reduced by almost 7 times, with much easier process of the damper manufacturing.

The experimental results confirmed the general position about greater efficiency of complex composite filters, and the correctness of the chosen method of their calculation proposed earlier by the authors; in particular, the attenuation level of pressure fluctuations for the designed damper coincided with calculations presented in [1] with a high degree.

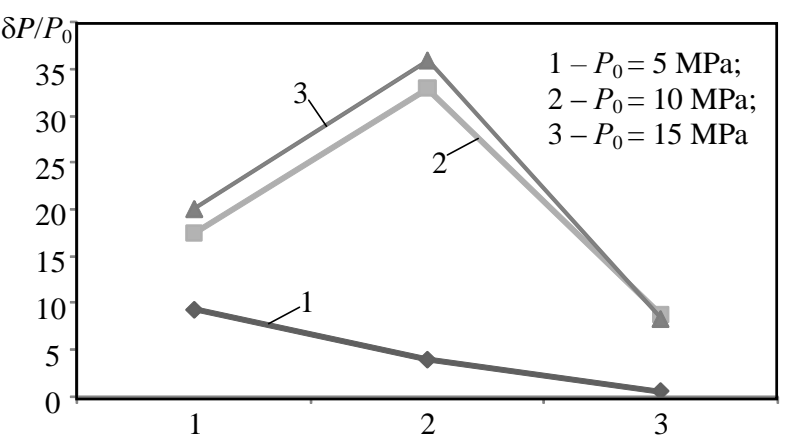

Fig. 6. The relative magnitude of pressure fluctuations along the length of line: regular damper, $n=1500 \mathrm{rpm}$, feed failure mode

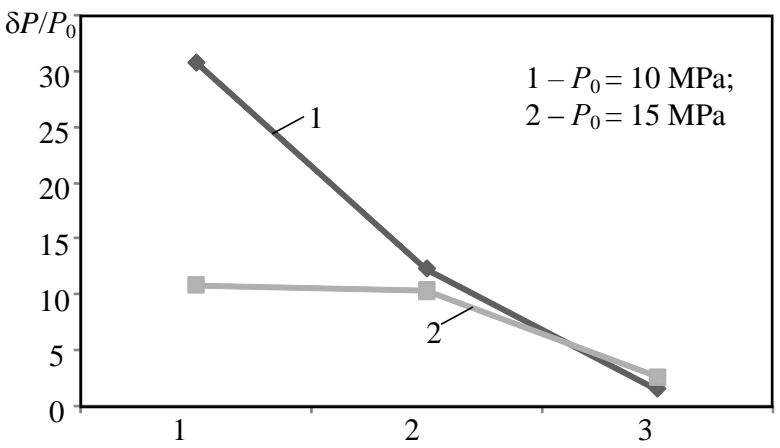

Fig. 8. The relative magnitude of pressure fluctuations along the length of line: damper $H=1.0 \mathrm{~m}, n=1500$ rpm, feed failure mode

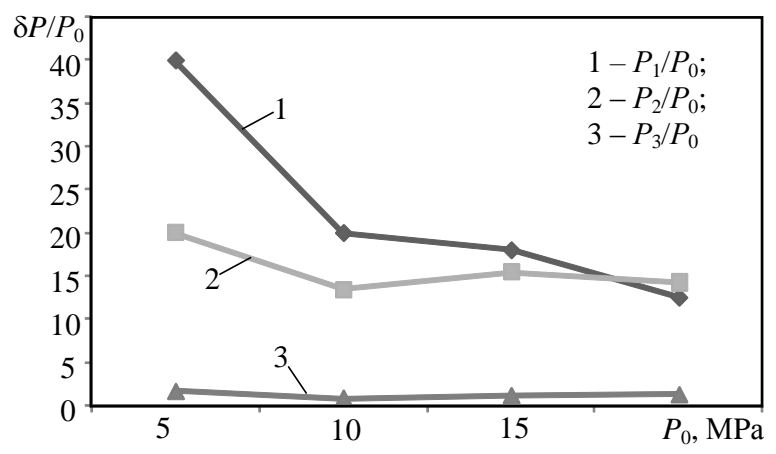

Fig. 9. The relative magnitude of pressure fluctuations as a function of the initial pressure: single piston pump, $n=980 \mathrm{rpm}$; damper $H=1.0 \mathrm{~m}$, normal operating mode 


\section{Література}

1. Korolyov, O.V. Dynamic damper pressure fluctuation in the pumping systems / O.V. Korolyov, Zhou Нuіуu // Пр. Одес. політехн. ун-ту. - 2016. - Вип. 1(48). - С. 35 - 40.

2. Ziegler, F. Special design of tuned liquid column-gas dampers for the control of spatial structural vibrations / F. Ziegler // Acta Mechanica. - 2008. - Vol. 201, Issue 1. - PP. 249 - 267.

3. Volk, M.W. Pump characteristics and applications / M.W. Volk. $-3^{\text {rd }}$ Ed. - Boca Raton: CRC Press, 2014. - 490 p.

4. Korenev, B.G. Dynamic vibration absorbers: theory and technical applications / B.G. Korenev, L.M. Reznikov. — Chichester: Wiley, 1993. — 296 p.

\section{References}

1. Korolyov, O.V., \& Zhou Huiyu. (2016). Dynamic damper pressure fluctuation in the pumping systems. Odes 'kyi Politechnichnyi Universytet. Pratsi, 1, 35-40. DOI:10.15276/opu.1.48.2016.07

2. Ziegler, F. (2008). Special design of tuned liquid column-gas dampers for the control of spatial structural vibrations. Acta Mechanica, 201(1), 249-267. DOI:10.1007/s00707-008-0062-2

3. Volk, M.W. (2014). Pump Characteristics and Applications ( $3^{\text {rd }}$ Ed.). Boca Raton: CRC Press.

4. Korenev, B.G., \& Reznikov, L.M. (1993). Dynamic Vibration Absorbers: Theory and Technical Applications. Chichester: Wiley. 